------ Raf. J. Sci., Vol. 22, No.4 pp 17-25, 2011------

\title{
Detection of Toxoplasma gondii Antibodies in Different Meat Juices
}

\author{
Ehsan G. Zakaria \\ Department of Pharmacy \\ Technical Institute \\ Mosul \\ E-mail: gorgeesehsan@yahoo.com
}

(Received 17/ 4 / 2011 ; Accepted 20 / 7 / 2011 )

\begin{abstract}
Toxoplasmosis is one of the most important zoonotic diseases worldwide and it is caused by the protozoan Toxoplasma gondii, humans can get infected post-naturally either by uptake of sporulated toxoplasma oocysts or by ingestion of tissue cysts upon consumption of raw or undercooked meat.

The study included cattle, sheep and chicken of different age groups and housing conditions whenever possible and applicable. Direct Latex Agglutination test was used to detect $T$. gondii specific antibodies and to determine seroprevalences in meat juice of slaughtered animals. The total samples are 300 of domestic animals (cattle, sheep and chicken 100 samples each of them).

The results of Latex agglutination test are positive in $17 \%$ of cattle, $37 \%$ of sheep and $9 \%$ of chicken from meat juice. The examination of specific IgG and IgM antibodies was detected by Hydroxy ethylmercaptan (2-ME) test with used of meat juices and Compound of 2- Hydroxy ethylmercaptan which appear in cattle $17.9 \%$ of IgM and $82.1 \%$ IgG, in sheep $16.2 \%$ of IgM and $83.8 \%$ IgG and in chicken $11.1 \%$ of IgM and $88.9 \%$ IgG.

The aim of this study was to approximate the risk of human infection via meat consumption by estimating the seroprevalence of $T$. gondii in slaughtered animals in Hamdania.
\end{abstract}

Keywords: Toxoplasma gondii; Toxoplasmosis; Antibodies, meat juices .

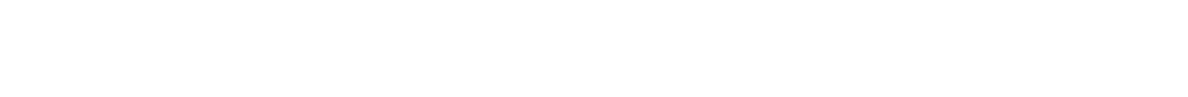

\section{|lll}

يعد داء المقوسلت الكوندية من أهم الأمراض المشتركة والذي يسببه طفيلي Toxoplasma gondii،

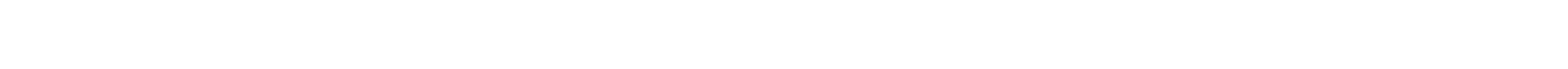




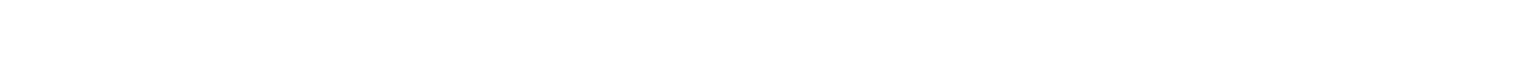

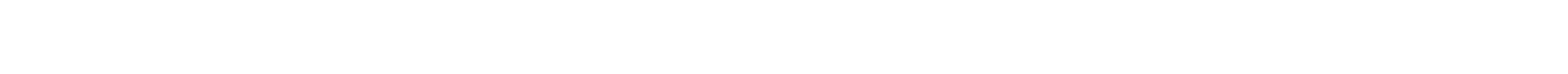

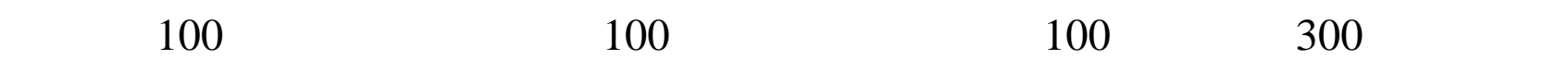
لحوم الدولجن. وأظلهرت نتائج فحص التلازن المبلثر إن نسبة الإصابة بلغت 17\% في الأبقار و37\% في الأغنلم

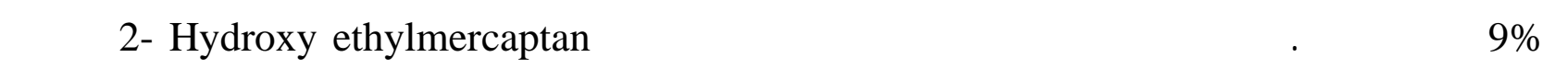

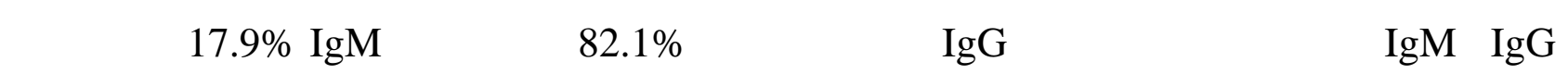

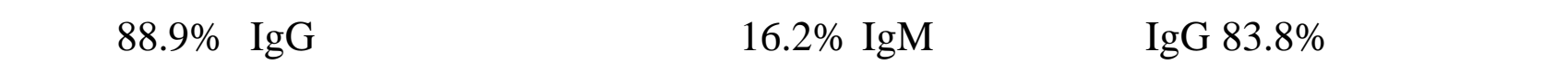
نسبة 11.1 19M IgM. وتساهم هذه الدرلسة في إمكانية انتقل هذا الطفيلي من قل لحوم الحيولنت المختلفة وان جميع العينت جمعت من المجازر المتولجة في مطقة الحمدانية.

\section{INTRADUCTION}

Toxoplasma gondii is an obligate intracellular protozoan that infect human and a wide range of mammalian and bird (Smith and Reduck, 2000) the parasite is known to cause congenital disease and abortion both in humans and livestock (Dubey and Beattie 1988; Remington and Desmonts, 1990). Maternal toxoplasmosis during early pregnancy of human may leads to death of fetus or cause chorioretinitis, hydrocephaly, microcephaly and jaundice in neonates (Joynson and Wreghitt, 2001; James, 2003).

In its life cycle, domestic and wild felines are definitive hosts while human, other mammals and birds are its intermediate hosts, Intermediate hosts acquire the infection by many main routes like Ingestion of oocysts in soil, sand or any other place where cats defecate, being disseminated by means of transport hosts such as flies, cockroaches and worms; ingestion of cysts in raw or undercooked meat and transplacentary infection (Dubey and Beattie, 1988; Ruiz and Frenkel, 1980).

The tissue parasitism during the proliferative phase may occur without symptoms (Joan, 2005). It may lead to a transient illness characterized by lymphadenopathy, fever, fatigue, arthralgia, dermatosis, malaise, headache, and myalgia (Pinard et al., 2005), any meat from warm-blooded animals and birds traditionally has been considered a major source of $T$. gondii infection in the world (Asgari et al., 2006).This idea stems from small outbreaks associated with the consumption of undercooked meat and several epidemiological studies, the consumption of undercooked meat is the most likely source of infection (Choi, 1997; Cook, 2000; Tenter et al., 2000).

\section{MATERIAL AND METHODS}

\section{Meat samples}

Meat samples (300 samples) were selected from a population collected for market and Hamdania slaughter the amount collected meat samples (100 grams) from each animals of cattle 100 samples, sheep 100 samples and chicken 100 samples, then deep freezing of these 
meat samples at $-18{ }^{\circ} \mathrm{C}$ and thawing at $20-25{ }^{\circ} \mathrm{C}$ and collect the meat juices about 2-5 ml in the tube. The study was approved in libratory of Dept. of Pharmacy, Institute of Technical in Mosul.

\section{Serological test}

\subsection{Latex Agglutination Test (LAT)}

Determination of $T$. gondii Antibody by latex agglutination test, depending on kit called Toxocell-latex with meat juices of cattle, sheep and chicken at room temperature by freezing individual meat samples at $-18 \stackrel{\circ}{\mathrm{C}}$ overnight, then thawing at $20-25 \mathrm{C}$ and using a commercial test kit. This kit uses formalin-fixed whole tachyzoites as antigen, and has been validated for use with pork samples (Gamble et al., 2005; Dubey et al., 2005 ) for testing cattle, sheep and chicken tissue fluids of $0.05 \mathrm{ml}$ of meat juices and $0.05 \mathrm{ml}$ of kit in clean slights by micropipette and then mixed by circle movement for 5 minutes and reported the result by macro examination or micro examination.

2.2. Indirect agglutination test

Positive samples of meat juices for toxoplasma antibody which selected in the first test, examined by Indirect agglutination test and 8 dilutions for selected meat juices were prepared.

\subsection{2-Hydroxy ethylmercaptan}

The compound 2-Hydroxy ethylmercaptan were used with selected positive meat juices for toxoplasma antibody, the 2-Hydroxy ethylmercaptan test identify the type of immunoglobulin IgG or IgM (Desmonts and Remington, 1980), $0.14 \mathrm{ml}$ of (0.2 M) 2Hydroxy ethylmercaptan were added to $10 \mathrm{ml}$ volumetric flask and volume completed using phosphate buffer saline ( $\mathrm{pH}=7.2)$ (Gould and Clegg, 1987) $0.1 \mathrm{ml}$ of 2- Hydroxy ethylmercaptan were added to $0.1 \mathrm{ml}$ of meat juices in clean test tube and incubated at (37 ${ }^{\circ} \mathrm{C}$ ) for one hour.

\section{RESULT}

The results appeared in table (1) of serological examination by direct latex agglutination test which appeared $17 \%$ were positive in cattle and $37 \%$ in sheep and $9 \%$ in chicken.

the results and of the direct latex agglutination test in table (2) showed that (17) sample positive in cattle, the titration of antibodies in meat juices, and in table (3) were show (37) sample positive of direct latex agglutination test in sheep meat juices, and in table (4) were show of (9) sample positive of direct latex agglutination in chicken meat juices The examination of specific IgG and IgM antibodies was detected by 2- Hydroxy ethylmercaptan test by using of meat juices and compound of 2- Hydroxy ethylmercaptan which appear in table (5) were positive of (17) of direct latex agglutination test in cattle $17.9 \%$ of IgM and $82.1 \%$ IgG, in sheep $16.2 \%$ of IgM and $83.8 \%$ IgG and in chicken $11.1 \%$ of IgM and $88.9 \%$ IgG. 
Table 1: Numeration study of meat juices of cattle, sheep and chicken samples infected with Toxoplasma gondii using Direct Latex Agglutination test.

\begin{tabular}{|c|c|c|c|c|c|}
\hline Meat juices & $\begin{array}{c}\text { No. of } \\
\text { samples }\end{array}$ & $\begin{array}{c}\text { No. of } \\
\text { positive }\end{array}$ & $\begin{array}{c}\text { \% of } \\
\text { positive }\end{array}$ & $\begin{array}{c}\text { No. of } \\
\text { negative }\end{array}$ & $\begin{array}{c}\text { \% of } \\
\text { negative }\end{array}$ \\
\hline cattle & 100 & 17 & $17 \%$ & 83 & $83 \%$ \\
\hline sheep & 100 & 37 & $37 \%$ & 63 & $63 \%$ \\
\hline chicken & 100 & 9 & $9 \%$ & 91 & $91 \%$ \\
\hline
\end{tabular}

Table 2: Titration of antibody in meat juices cattle for positive infected with Toxoplasma gondii using Indirect Agglutination test.

\begin{tabular}{|c|c|c|c|c|c|c|c|c|c|c|c|c|}
\hline No. of & No. of & \multicolumn{9}{|c|}{ Titration of antibody } \\
\cline { 3 - 14 } & $\begin{array}{c}\text { positive } \\
\text { samples } \\
\text { In(LAT) }\end{array}$ & $1 / 2$ & $1 / 4$ & $1 / 8$ & $1 / 16$ & $1 / 32$ & $1 / 64$ & $1 / 128$ & $1 / 256$ & $1 / 512$ & $1 / 1024$ & $1 / 2048$ \\
\hline 100 & 17 & - & - & 1 & 1 & 2 & 4 & 3 & 2 & 3 & 1 & - \\
\hline
\end{tabular}

Table 3: Titration of antibody in meat juices sheep for positive infected with Toxoplasma gondii using Indirect Agglutination test.

\begin{tabular}{|c|c|c|c|c|c|c|c|c|c|c|c|c|}
\hline No. of & No. of & \multicolumn{10}{|c|}{ Nitration of antibody } \\
samples & $\begin{array}{c}\text { Nositive } \\
\text { samples } \\
\text { In(LAT) }\end{array}$ & $1 / 2$ & $1 / 4$ & $1 / 8$ & $1 / 16$ & $1 / 32$ & $1 / 64$ & $1 / 128$ & $1 / 256$ & $1 / 512$ & $1 / 1024$ & $1 / 2048$ \\
\hline 100 & 37 & - & - & 1 & 3 & 2 & 4 & 5 & 13 & 7 & 1 & 1 \\
\hline
\end{tabular}

Table 4: Titration of antibody in meat juices chicken of positive infected with Toxoplasma gondii using Indirect Agglutination test.

\begin{tabular}{|c|c|c|c|c|c|c|c|c|c|c|c|c|}
\hline No. of & No. of & \multicolumn{9}{|c|}{ Titration of antibody } \\
\cline { 3 - 13 } samples & $\begin{array}{c}\text { positive } \\
\text { samples } \\
\text { In(LAT) }\end{array}$ & $1 / 2$ & $1 / 4$ & $1 / 8$ & $1 / 16$ & $1 / 32$ & $1 / 64$ & $1 / 128$ & $1 / 256$ & $1 / 512$ & $1 / 1024$ & $1 / 2048$ \\
\hline 100 & 9 & - & - & - & 1 & 2 & 5 & 1 & - & - & - & - \\
\hline
\end{tabular}


Table 5: specific IgG and IgM antibodies in cattle, sheep and chicken of positive infected with Toxoplasma gondii by using 2- Hydroxy ethylmercaptan test

\begin{tabular}{|c|c|c|c|c|c|}
\hline $\begin{array}{c}\text { Meat } \\
\text { juices }\end{array}$ & $\begin{array}{c}\text { No. of } \\
\text { positive } \\
\text { In (LAT) }\end{array}$ & No. IgM & \% & No. IgG & \% \\
\hline cattle & 17 & 3 & $17.9 \%$ & 14 & $82.1 \%$ \\
\hline sheep & 37 & 6 & $16.2 \%$ & 31 & $83.8 \%$ \\
\hline chicken & 9 & 1 & $11.1 \%$ & 8 & $88.9 \%$ \\
\hline
\end{tabular}

\section{DISCUTION}

Toxoplasmosis is one of the most common human infections throughout the world, infection is more common in warm climates and at lower altitudes than in cold climates and mountainous regions (James, 2003). Sporulated T. gondii oocysts are very resistant to environmental conditions, and remain infective in humid soil for more than 18 months. However, they do not survive long under cold or dry conditions (Dubey et al., 2000). There are two basic forms of toxoplasma organism: the "oocyst," which is shed in the cat feces, and the toxoplasma tissue stages, which found in cattle and sheep (Khadi et al., 2009). A person who inadvertently eats either of these forms of toxoplasma is expose to become infected. When the infected person is a pregnant woman, the toxoplasma organism may cross into the placenta (Remington and Desmonts, 1990), the amount of damage done to the mother and the fetus baby depends on the stage of pregnancy at the time of infection. Infection in early pregnancy may result in miscarriage or stillbirth or in a child with varying degrees of blindness and/or various severe neurological conditions including hydrocephalus, microcephaly, and retardation (Mead et al., 1999). The ingestion of infected uncooked pork was believed to be a major meat source of T. gondii infection for humans in the world (Joan, 2005; Mead et al., 1999).

Diagnosis of toxoplasmosis in cattle, sheep and chicken 100 samples for each, in this study was depended upon serological test like direct latex agglutination test, it was useful in positive exploring $17 \%$ cattle, $37 \%$ in sheep and $9 \%$ in chicken to $T$. gondii infection through contaminated meat with parasite. The positive modified latex agglutination test used the compound 2-Hydroxy ethylmercaptan, means that IgG antibodies superimpose on IgM antibodies and that the infection was a chronic one. This suggestion could be traced by the purchased rabbit, show no symptoms of infection, so may samples acquired their infection from their infected dose, which pass their IgG antibodies through placenta and suppressing IgM antibody which response in their offsprings (Araujo and Reminogton,1975; Aghwan et al., 2010).

The moderate titers of antibodies (up to 512) of the tested cattle, sheep and chicken may also explain the chronic of infection. This study has found a high seroprevalence in chicken are 9\% that is different than those of (Ghorbani et al., 1990; Dubey et al., 2005; Devada et al., 2005), found 33\%, 36.3\%, and 39.5\% in Free-chicken from Iran, Austria, and India respectively. the high prevalence of toxoplasmosis in chickens was in Iran (Asgari et al., 2006). However the prevalence is markedly close to the values detected in Brazil (Asgari et 
al., 2006) United States (Dubey et al., 2003) and Peru (Dubey et al., 2004), where their reported are $10.3 \%, 17 \%$ and $26 \%$ rates were reported respectively. The clinic signs in birds are normally severe, ocular and cerebral lesions, which affect on canaries and turkeys to penguins. In trials involving birds, little is known on clinical signs. Several authors studied the experimental infection in wild and domestic birds. However, this kind of report involves only the immunological response of the animals to T. gondii, in animals are euthanized soon after the immune response is recorded, leaving a lot to be studied (Williams et al., 2001; Lindsay et al., 1995).

The moderate titers of antibodies (1/64 - 1/512) of the tested cattle, sheep may explain the chronic of infection. This study has found a high seroprevalence in cattle $17 \%$ and that are closet to those of Dahan et al., 1983 in France (27.42\%) and Knapen et al., 1982 in Newsland (22\%), and different to those of Horio et al., 2001 in Kitakyushu city (33.9\%) and Garrido et al., 1972 in Spin (36\%). And this study has found a high seroprevalence in sheep 37\% that are closet to those of Rifaat et al., 1978 (34\%) in Egypt and with Amin and Morsy, 1997 (39\%) in Jeddah. And deferent to those of Silva and Hangoni, 2001(7.7\%) in Brazil and Chhabra et al., 1982 (19.6\%) in India. The causes of increase positive percentage in meat juice of cattle and sheep in hamdania slaughter are deferent environments of animal slaughter and animals are not examined by toxoplasma test before slaughter and we can't diagnosis of subclinical case and the animals not appear any clinical singes.

Many animals used for meat production show evidence of a $T$. gondii infection are measured via serum antibodies, and viable parasites have been isolated from the meat of these animals with the exception of cattle (Tenter et al., 2000; Efas 2007). Meat as a source of infection in human relates to the observation that the decline in human $T$. gondii seroprevalence (Jones et al., 2007), parallels the decrease in seroprevalence in animals transmitted by food (Kijlstra et al., 2004), It has been suggested that the introduction of indoor farming has led to a marked drop in the T. gondii seroprevalence in pork, but public demand for animal-friendly outdoor production systems has led to a re-emergence of toxoplasma infection in these animals (Schulzig and Fehlhaber, 2006; Giessen et al., 2007).

Many factors such as management and hygienic standards in breeding, density of cats and environmental conditions are effective on the acquisition of $T$.gondii oocysts by animals (Jones et al., 2007). The rate of toxoplasmosis in free-ranging chicken is an important indicator of environmental contamination because of food habits (Araujo and Reminogton, 1975; Devada et al., 1998).

Little is known on the clinical symptoms of toxoplasmosis in ratites in general, and specifically in ostriches, and their implications to the breeding of these animals. Then heating is the most efficient way to kill $T$. gondii tissue cysts. Meat should cooked at internal temperatures of $56-58{ }^{\circ} \mathrm{C}$ at least for ten minutes (Dubey et al., 1990). Freezing the meat at least for two days at temperatures below $-18 \mathrm{C}$ can also kill tissue cysts (Kotula et al., 1991). Curing and treatment of meat with eshancing solutions, such as potassium or sodium lactate, can also kill $T$. gondii tissue cysts. Inactivation of tissue cysts depends on the interaction between salt concentration, maturation time and temperature. 


\section{REFERANCES}

Aghwan, S.S., Al-Taee, A.F; Suliman, E.G. (2010). Detection of Toxoplasma gondii infection in domestic rabbits by using multiple techniques. Iraqi J. of Vet. Sci., 24 (2), 65-69.

Amin, A.; Morsy, T. (1997). Anti-toxoplasma antibodies in butchers and slaughtered sheep and gout in Jeddah. J. Egypt. Soc.Parasitol. 27(3), 913-918.

Araujo, F.G.; Reminogton, J.S. (1975). IgG antibody suppression of the IgM antibody response to Toxoplasma gondii in newborn rabbits. J. Immunol., 115, 335-338.

Asgari, Q.; Farzaneh, A.; Kalantari, M.; Akrami, F.; Moazeni, M.; Zarifi, M.; Motazedian, M.H. (2006). Seroprevalence of free-ranging chicken toxoplasmosis in Sub-Urban, International J. Poultry Sci. 5 (3), 262-264.

Chhabra, M.B.; Mahajan, R.C. (1979). Prevalence of Toxoplasma gondii antibodies in Zeba cattle India. Trop. Anim. Hith Prod. 11, 27-28

Choi, W.Y. (1997). Foodborne outbreaks of human toxoplasmosis. J. Infect. Dis., 175, $1280-1282$.

Cook, A. J. (2000). Sources of toxoplasma infection in pregnant women: European multicentre case-control study, 321,142-147.

Dahan, R.H.; Heinrich, A.; Ferry, R. (1983). Human and animals toxoplasmosis in Strasbourg area in 1980. Modification observed since 1970. Med. Malad. Infec. 13 (8), 457-459.

Desmonts, G.; Remington, J. (1980). Direct agglutination test for diagnosis of Toxoplasma gondii: method for increasing sensitivity and specificity. J. Clin. Microbial., 11, 562-568.

Devada, K.; Anandan R.; Dubey, J.P. (1998). Serologic prevalence of Toxoplasma gondii in chickens in Madras, India. J. Parasitol., 84, 621-622.

Dubey, J. P.; Beattie, C. P.( 1988). Toxoplasmosis of animals and man. Boca Raton: CRC Press, 1-220.

Dubey, J.P.; Hill, D.E.; Jones, J.L.; Hightower, A.W.; Lehmann, T. (2005). Retail meat stores in the United States: prevalence of Viable Toxoplasma gondii in beef, chicken, and pork from risk assessment to Consumers. J. Parasitol., 91(5), 10821093.

Dubey, J.P.; Klein, J.O.; Levy, M.Z. (1990). Effect of high-temperature on infectivity of Toxoplasma gondii tissue cysts in pork. J. Parasitol., 76, 201-204.

Dubey, J.P.; Graham, D.H.; Dahl, E.; Screekumar, C.; Lehmann, T.; Davis, M.F.; Morishita, T.Y. (2003). Toxoplasma gondii isolates from free-ranging chickens from the United States. J. Parasitol., 89, 1060-1062.

Dubey, J.P.; Edelhofer, R.; Marcet, P.; Vianna, M.C.; Kwok, O.C; Lehmann, T. (2005). Genetic and biologic characteristics of Toxoplasma gondii infections in free-range chickens from Austria. Vet. Parasitol., 133, 299-306.

Dubey, J. P.; Scandrett, W.B.; Kwork, O.C.H.; Gajadhar, A.A. (2000). Prevalence of antibodies to Toxoplasma gondii in ostriches Struthio camelus. J. Parasit., 86 (3), 623-624,.

Dubey, J.P.; Levy, M.Z.; Screekumar, C.; Kwok, O.C.; Shen, S.K.; Dahl, E.; Thulliez P.; Lehmann, T. (2004). Tissue distribution and molecular characterization of chicken isolates of Toxoplasma gondii from Peru. J. Parasitol., 90, 1015-1018. 
EFSA, A. (2007). Monitoring of toxoplasma in humans, food and animals. Scientific opinion of the panel on biological hazards. EFSA J., 583, 1-64.

Gamble, H.R.; Brady, R.C.; Dubey, J.P. (2005). Comparison of a commercial ELISA with the modified agglutination test for detection of Toxoplasma infection in the domestic pig. Vet. Parasitol., 128, 177-181.

Garcia, J. L.; Navarro, I.T.; Ogawa L.; Marana, E.R. (2000). Seroprevalência do Toxoplasma gondii emgalinhas (Gallus gallus domesticus) de criaçoes domésticas, oriundas, oriundas depropriedades rurais do norte do paraná, Brasil. Ciênc Rural. (Santa Maria). 30, 123-127.

Gebreyes, W. A.; Screekumar, C.; Tauxe, R. (2008). Seroprevalence of trichinella, toxoplasma, and salmonella in antimicrobial-free and conventional swine production systems. Foodborne Pathog. Dis., 5, 199-203.

Ghorbani, M.; Gharavi, M.J.; Kahnamoui, A. (1990). Serological and parasitological investigations on toxoplasma infection in domestic fowls in Iran. Iranian. J. Pubic. Health, 19, 9-17.

Giessen, J.; Levy, M.Z.; Screekumar, C.; Tauxe, R (2007). Seroprevalence of Trichinella spiralis and Toxoplasma gondii in pigs from different housing systems in The Netherlands. Vet. Parasitol., 148, 371-374.

Gould, E. A.; Clegg, J. C. (1987). " Growth: Titration and Purification of Alpha Viruses and Flavi Viruses". In Press. Oxford, pp.65-67.

Horio, M.; Nakamura, K.; Shimada, M. (2001). Risk of Toxoplasma gondii infection in slaughterhouse workers in Kitakyushu city. J. Uoeh. 23(3),233-243.

James, D. (2003). "Determination of Toxoplasma gondii Antibody Prevalence in Midwest Investigator": McKean institution: Iowa State University Date Received.

Joan, K. (2005). Use of molecular assays to assess Toxoplasma gondii burden in commercial meat samples investigator: Institution: Anri, Barc, ARS, USDA, B.1040), Beltsville, MD 20705.

Jones, J.L.; Heckeroth, A.R.; Weiss, L.M. (2007). Toxoplasma gondii infection in the United States, 1999-2004, decline from the prior decade. Am. J. Trop. Med. Hyg., 77, 405-410.

Joynson, D.H;. Wreghitt, T.G. (2001). "Toxoplasmosis: a comprehensive clinical guide". Cambridge University Press, pp.193-276.

Khadi, J. A.; Thamer, M. K.; Al-amin, A. (2009). Prevalence of antibodies to Toxoplasma gondii in aborted ewes in south of Iraq. Iraqi J. Vet. Sci., 23(1), 199-202.

Kijlstra, A.; Tauxe, R.; Brady, R. (2004). Toxoplasma gondii infection in animal-friendly pig production systems. Invest. Ophthalmol. Vet. Sci., 45, 3165-3169.

Knapen, F.V.; Franchimont, J.H.; Lugt, G. (1982). Prevalence of antibiotic to toxoplasma in farm animals in the nether and implication for meat inspection. Vet. Quarterly. 4 (3), 101-105.

Kotula, A.W.; Akrami, F; Akrami, F. (1991). Effect of freezing on infectivity of Toxoplasma gondii tissue cysts in pork. J. Food Prot., 54, 687-690.

Lindsay, D. S.; Gasser, R. B.; Harrigan, K. E.; Madili, D. N.; Blagburn, B. L. (1995). Central nervous system toxoplasmosis in Roller canaries. Avian Dis., 39 (1), 204207. 
Mead, P. S.; Slutsker, L. V.; Dietz, L. F.; Mccaig, J. S.; Bresww, C.; Shapiro, P. M.; Griffin,; Tauxe, R. V. (1999). Serological survey of antibodies to Toxoplasma gondii. Emerging Infec. Dis., 5, 607-624.

Pinard, J A. ; Leslie, N. S.; Irvine, P. J. (2003). Maternal serologic screening for toxoplasmosis. J. Midwifery Women's Health. 48 (5), 308-386.

Remington, J.S.; Desmonts, G. (1990). Toxoplasmosis. In: Remington, J.S.; Klein, J.O., eds. Infectious diseases of the fetus and newborn infant. Philadelphia (Santa Maria). 30, 123-127.

Rifaat, M.A.; Morsy, T.A.; Sadek, M.S.; Safar, E.H. (1978). Prevalence of Toxoplasma gondii antibodies among slaughtered animals in Lower Egypt. J. Egy. Soci. Parasitol. 8 (2),339-345.

Ruiz, A.; Frenkel, J.K. (1980). Intermediate and transport hosts of Toxoplasma gondii in Costa Rica. Amer. J. Trop. Med. Hygiene, 29 (6), 1161-1166.

Schulzig, H.S.; Fehlhaber, K. (2006). Seroprevalence of Toxoplasma gondii in conventionally and organically produced pork and porkproducts. Fleischwirtschaft, 86, 106-108.

Silva, L. J.; Langoni, H. (2001). The Detection of Toxoplasma gondii by comparing cytology, histopathology, bioassay in mice and the polymerase chain reaction. Vet. Parasitol. 97, 191-197.

Smith, J.E.; Reduck, N.R. (2000). Toxoplasma gondii strain variation and pathogenicity. In: Cary, J.W.; Linz, J.E.; Bhatnagar, B. (Eds), Microbial Foodborne Diseases: Mechanisms of Pathogenesis and Toxin Synthesis. Technnomic Publishing, Lancaster, PA, 405-431.

Tenter, A.M.; Heckeroth, A.R.; Weiss, L.M. (2000). Toxoplasma gondii: From animal to human. Inter. J. for Parasitol. 30, 1217-1258.

Williams, S. M.; Fulton, R. M.; Render, J. A.; Mansfield, L.; Bouldin, M. (2001). Ocular and encephalic toxoplasmosis in canaries. Avian Dis., 45(1), 262-267. 